Canadian Journal of Higher Education Revue canadienne d'enseignement supérieur

Volume 46, No. 2, 2016, pages 19 - 39

\title{
Reframing Internationalization
}

Kyra Garson

Thompson Rivers University

\begin{abstract}
Canadian higher education has long been involved in international education, partnerships, and research and development projects; however, recent framing of international education as an industry generating revenues to prop up underfunded institutions is troubling. This approach is endorsed by provincial government strategies and bolstered by the federal government's recent International Education Strategy, which promotes doubling the recruitment of international students by 2022 (Canada, 2014). While it is true that international students bring economic benefits to the institutions and communities that host them, we should also consider the challenges that this numbers game potentially presents for education. Many institutions now strive to internationalize; although this can encompass a broad range of activities, for many, the focus has been on increasing international student enrolment. This paper argues that there is a need to reframe internationalization in Canada in a way that would acknowledge the economic rationales, yet balance them with the social and academic outcomes necessary for all students to develop the knowledge, attitudes, and skills necessary for effective participation as professionals and citizens in increasingly multicultural and global contexts. For internationalization to fully reach its potential, a reframing of internationalization at home, informed by critical global citizenship education, may offer a way to realize the social and academic outcomes that would support an ethical, inclusive, and equitable approach moving forward.
\end{abstract}

\section{Résumé}

Bien que le milieu de l'enseignement supérieur au Canada soit engagé depuis longtemps en matière d'éducation internationale, de partenariats, et de projets de recherche et de développement, l'encadrement récent de l'éducation à titre d'industrie profitable pour pallier le sous-financement de certaines institutions est troublant. Cette approche est entérinée à la fois par les instances provinciales et fédérales, notamment par la nouvelle Stratégie pour l'éducation 
internationale, qui vise à doubler le recrutement d'étudiants internationaux d'ici 2022 (Canada, 2014). Sans nier les apports économiques de ces étudiants pour les institutions et collectivités qui les accueillent, nous devrions également prendre en considération les défis potentiels pour l'éducation que ces nombres dissimulent. Aujourd'hui, alors que beaucoup d'institutions luttent pour s'internationaliser par divers moyens, un nombre grandissant s'oriente principalement vers la majoration du recrutement d'étudiants internationaux. Nous proposons ici un recadrage de l'internationalisation au Canada, de façon à reconnaître les retombées économiques qu'il engendre tout en les pondérant avec les résultats sociaux et académiques nécessaires à tous les étudiants pour perfectionner leurs connaissances, attitudes et aptitudes, fondamentales à une participation efficace à titre de professionnels et de citoyens dans des contextes de plus en plus multiculturels et mondiaux. Pour que l'internationalisation atteigne son plein potentiel, un recadrage au Canada, éclairé par une éducation citoyenne essentielle et planétaire, peut devenir une façon d'accomplir des résultats socioéconomiques qui soutiendraient à l'avenir une approche éthique, inclusive et équitable.

\section{Introduction}

Canadian higher education has long been involved in international education, partnerships, and research and development projects; however, the recent framing of international education as an industry generating revenues to prop up underfunded institutions is troubling. This approach is endorsed by provincial government strategies and bolstered by the federal government's recent International Education Strategy, which promotes doubling the recruitment of international students by 2022 (Canada, 2014). While it is true that international students bring economic benefits to the institutions and communities that host them, we should also consider the challenges that this numbers game potentially presents for education. Many institutions now strive to internationalize, and although this can encompass a broad range of activities, for many, the focus has been on increasing international student enrolment. This paper argues for the need to reframe internationalization in Canada in a way that would acknowledge the economic rationales, and yet balance them with the social and academic outcomes necessary for all students to develop the knowledge, attitudes, and skills required for effective participation as professionals and citizens in increasingly multicultural and global contexts. The current state of internationalization is reviewed, followed by a discussion of the influence of globalization on education; these provide the context for the argument that a renewed focus on internationalization at home ( $\mathrm{I} @ \mathrm{H})$, informed by critical global citizenship education, has the potential to close the gap between the rhetoric and the reality of internationalization.

\section{Internationalization: Where Do We Go From Here?}

Internationalization is a contested and variously interpreted term. Many scholars acknowledge the difficulty of definitions or of terms-internationalism, internationalization, globalization-that often are used interchangeably or mistakenly (Bond, 2006; de Witt, 2011; Enders, 2004; Harris, 2008; Knight, 2004; Stromquist, 2007). Indeed, 
Knight (2004) reminded us that the debate around terminology has been ongoing since the mid-1980s. Three decades later, Harris (2008) posed the question: "What does 'international' mean?" (p. 346).

The internationalization of education has been rationalized as a response to globalization, as a means for institutions to "cope with or exploit globalization" (Altbach, 2004, p. 3). These positions - "to cope with or to exploit"-are the foundation of the divide evident in the literature and go to the heart of the question as to whether internationalization is a mechanism for institutional revenue (Harris, 2008; Stromquist, 2007) within a competitive educational market, or a means to adapt education to global contexts and embrace potential opportunities for real change in terms of curriculum and learning outcomes in the form of global citizenship education (Gacel-Avila, 2005; Pike, 2008; Shultz, 2011; Swanson, 2011; Tarc, 2011) or intercultural education (Bond, 2006; Deardorff, 2006; Leask, 2010; Paige \& Mestenhauser, 1999).

Scholars of internationalization have warned that a balanced approach is critical to its success and sustainability (Beck, 2012; Brandenburg \& de Wit, 2010; de Wit, Hunter, Howard, \& Egron-Polak, 2015; Leask, 2012). Concern has been growing that the focus on outputs, in terms of numbers or activities rather than outcomes for learning, may be detrimental. Indeed, Brandenburg and de Witt (2011) have pondered "the end of internationalization" (p. 27) and have invited educators to reconsider internationalization as a means to a goal rather than a goal in and of itself. According to Universities Canada (2014), 84\% of institutions place graduating internationally knowledgeable and interculturally competent students in their top five rationales for internationalization. However, the institutional or governmental rhetoric that internationalization produces global citizens is optimistic and not necessarily grounded in the reality of students negotiating intercultural tensions in our classrooms and on our campuses (Garson, 2013). Studies of student experience illuminate another reality: Canadian students count international peers as a mere $11 \%$ of their friends (Grayson, 2008), 56\% of international students claim to have not even one Canadian friend (Canadian Bureau for International Education, 2013), and many international students have reported that they are dissatisfied with their interactions with their Canadian peers (Beck, 2008). It is true the world is on campus, but without careful and intentional curricula and pedagogy to promote learning across difference, we may actually be producing graduates with more biases and stereotypes than when they entered our institutions.

The Canadian Bureau for International Education (2015) has reported an 83\% increase in international student enrolment in Canada since 2008. However, these enrolments are not the only factor contributing to the socio-cultural shifts in student demographics. To reframe internationalization in the Canadian context, it is important to acknowledge the multiple sources of increased cultural diversity that are transforming classrooms and campuses. Aboriginal youths represent one of Canada's few growing populations, with almost half a million presently under the age of 25 (Universities Canada, 2015). Immigration has and will continue to give rise to cultural diversity on Canadian campuses. Statistics Canada (2011) has projected that by 2031, almost half (46\%) of Canadians over the age of 15 will have been born outside of Canada or have parents born in another part of the world. If we are to reframe internationalization within social and academic rationales, Canadian educators will need to consider both the global and the local and recognize the uniqueness of our context as a nation of immigrants living on Indigenous peoples' territories. 
Considering these statistics, it would appear that Canadian higher education is poised to be a site of intercultural exchange and learning, although quantitative indicators do not account for the powerful hegemonic traditions that promote assimilation into mainstream norms (Abdi, 2011; Banks, 2009; Camicia \& Franklin, 2010; Kincheloe \& Steinberg, 2008; Kuokkanen, 2008; Otten, 2009). Canadian higher education follows an established curriculum designed from a specific cultural worldview that may subjugate or fail to acknowledge "an entire set of historical assumptions about 'tradition,' about the existence of a social consensus over what should count as legitimate knowledge, and about cultural superiority" (Apple, 2000, p. 68).

\section{Defining Internationalization}

Current demographic shifts have offered educators a myriad of opportunities to promote intercultural understanding and globally minded orientations if we are intentional in our approach. Intentionality is key. Fortunately, a new rendition of Knight's (2004) widely cited definition includes this concept, defining internationalization as:

the intentional process of integrating an international, intercultural or global dimension into the purpose, functions and delivery of post-secondary education, in order to enhance the quality of education and research for all students and staff, and to make a meaningful contribution to society. (de Wit et al., 2015, p. 29)

This definition supports new ways of thinking about internationalization, since it focuses on academic endeavours and education for the public good. Another definition by Hudzik (2011) discussed comprehensive internationalization:

Comprehensive internationalization is a commitment, confirmed through action, to infuse international and comparative perspectives throughout the teaching, research, and service missions of higher education. It shapes institutional ethos and values and touches the entire higher education enterprise. It is essential that it be embraced by institutional leadership, governance, faculty, students, and all academic service and support units. It is an institutional imperative, not just a desirable possibility.

Comprehensive internationalization not only impacts all of campus life but the institution's external frames of reference, partnerships, and relations. The global reconfiguration of economies, systems of trade, research, and communication, and the impact of global forces on local life, dramatically expand the need for comprehensive internationalization and the motivations and purposes driving it. (p. 6)

Hudzik's definition complements the 2015 definition cited above by introducing a few key elements that may inform any reframing of internationalization. First, it demands action, which will be critical if internationalization is to achieve its full potential as a foundation for 21st-century learning. Second, it highlights the comparative perspectives that are critical to an inclusive approach. Finally, it discusses a whole-campus approach, with an acknowledgement of not only the global but the local, which is important for conveying the relevance to all educational stakeholders. Although both of these definitions are il- 
lustrative of recent evolutions in internationalization, given the current rapid, globalizing influences on higher education, the reframing of internationalization may require more than updating definitions.

\section{Globalization and Higher Education}

A number of the concepts within this paper involve contested terms that may be employed in contradictory tones, depending on perspective. It is important to recognize that terms such as globalization and internationalization not only are contested within Western scholarship but also are increasingly defined and understood through Western scholarship (Abdi, 2011; Bourdieu, 2003; Santos, 2006; Shultz, 2011). As Appadurai (2001) pointed out, the uneven economic processes of globalization may inherently limit the possibility of a global view of globalization, due to unequal access to the educational resources needed to produce this global view. Therefore, as we theorize about internationalization and globalization, it is important to remember that those who might most strongly oppose generalizing definitions may not have a voice in the predominant discourses. It is even more critical for educators to interrogate quasi-accepted notions of such generalizing terms, since the real-world implications may be contrary for many who do not have access to education, resources, or even basic human rights.

Globalization "remains an inexact term" (Stromquist \& Monkman, 2014, p. 3) that continues to evolve (Marginson, 2011), with varied interpretations across disciplines and dispositions. Scholars across a variety of disciplines have grappled with this concept, and it is useful to consider various positions for how they may inform this inquiry. Jones (2010) has noted that a definition of globalization remains contentious, since many, often divergent, views have frequently been minimized to a polarization of globalization as either good or bad. So, Jones has attempted to categorize the key thinkers on globalization into categories that range from systemic, conceptual, sociological, transformational, sceptical, spatial, positive, reformist, and revolutionary to cultural paradigms.

Arjun Appadurai is the scholar that Jones associates with a cultural framing of globalization. Appadurai (2001) understands globalization as multiple manifestations whose workings represent inherent disjunctures that require further theorizing. He has proposed a framework of multiple "scapes" to examine the relationship between global flows of people, media, technology, economics, and knowledge, which he calls "ethnoscapes, mediascapes, technoscapes, financescapes, and ideoscapes" (p. 33); envisioning these "scapes," Appadurai has theorized beyond dualistic or flat understandings to a dynamic movement of multiple flows of people and ideas across borders and imaginaries. However, although Appadurai provided an inclusive framework that allows multiple interpretations and experiences to be a part of the globalization discourse, he fell short of providing a tangible interpretation of globalization as it relates to a shared understanding within the field of education. Beck (2012) has suggested an additional scape, an "eduscape," as a way to articulate internationalization and its relationship to globalization, noting that we cannot understand one scape without the others, since they all intersect with and bump up against one another. While trying to interrupt the current trajectory of commercial internationalization, it is helpful to consider the interactive nature of these scapes, because as Beck (2012) pointed out, "sometimes an eduscape could be driven by financescapes, and other times, initiated by a combination of ethnoscapes and ideoscapes" (p. 142). 
Popular understandings of globalization rarely consider the type of multidimensional conceptualizations advocated by Appadurai, Beck, and others; instead, these popular understandings more often reflect one-dimensional understandings that have been embedded in popular use, resulting in what Jones (2010) has claimed is an "overused, over-hyped concept" (p. 1) that few question. Indeed, globalization has become a quasiaccepted paradigm influencing lives and interactions around the world. It has become a common phrase popularized by the media and used by many either to praise the potential of free markets to flatten the world (Friedman, 2005) or to criticize the very same markets for creating inequities (Klein, 2000) or for playing a part in current natural and social disasters (Klein, 2008). The framing of globalization continues to generate a variety of contested understandings, often operating simultaneously (Burbules \& Torres, 2000; Conversi, 2010; Jones, 2010; Popkewitz \& Rizvi, 2009; Santos, 2006). Conversi (2010) has suggested that part of the lexical confusion is due to the "failure to distinguish globalization as an ideology and globalization as a practice" (p. 48). Popkewitz and Rizvi (2009) have highlighted the ideological aspects by describing the hegemonic infusion of a market orientation in all globalization rhetoric-a truth for which no one is accountable. Perhaps this is what Bourdieu (2003) has referred to as the "fake universalism" (p. 23) of the globalization rhetoric that he sees as serving the interests of the new transnational elite. Although many scholars have critiqued both the concept and the practice of globalization, many also have noted the prevailing inevitability that pervades much of the discourse (Altbach \& Teichler, 2001; Burbules \& Torres, 2000). Burbules and Torres have urged educators not to succumb to the rhetoric of inevitability and instead to frame going forward in a corrective manner that positions the global "in more equitable, and more just ways" (p. 61). So, while ideologically we may favour multiple conceptions of globalizing forces or scapes, when considering the current economic directives for internationalization, it is necessary to focus on neoliberal globalization in the context of education in which economic rationality, profit maximization, and a consumer ethic have become central tenets (Apple, 2000). Although neoliberalism has influenced education broadly, it has impacted internationalization more specifically in that it promotes the international expansion of markets, private funding, and education as a capitalist venture through a focus on marketization without borders, whereby financial gain often supersedes concerns about the public good.

In his Massey Lecture and subsequent book The Short History of Progress, Ronald Wright (2004) reminded us of the dangers of progress at any cost:

The most compelling reason for reforming our system is that the system is in no one's interest. It is a suicide machine. . It may also be little more than a mix of inertia, greed, and foolishness encouraged by the shape of the social pyramid. The concentration of power at the top of large-scale societies gives the elite a vested interest in the status quo; they continue to prosper in darkening times long after the environment and general populace begin to suffer. (p. 131)

His warnings are relevant to the current neoliberal influences on higher education, and the internationalization of higher education in particular. In their outline of various accounts of globalization, Burbules and Torres (2000) have identified the neoliberal account as an inherently inequitable ideology and warned that if education carries on with- 
out addressing globalization in tangible ways, it runs serious risks. Santos (2012) has asserted that the university is undergoing a "paradigmatic transition" under globalization that is summed up by the fact that "we face modern problems for which there are no modern solutions" (p. 8). For Santos, these modern problems are epitomized by our inability to reach the ideals of the French Revolution and realize liberté, egalité, and fraternité. Like Appadurai (2001), Santos (2006) has proposed conceptualizing "globalizations" in the plural, and he believes that the growing set of prescriptions framed by the hegemonic, monocultural, neoliberal consensus are most dangerous. This aspect of Santos' (2012) interpretation is the most chilling and calls upon educators and researchers to interrogate how intercultural and global learning are running the real risk of being usurped by market-driven ideologies. Critical scholars have stressed the need for educators and institutions to be accountable for promoting social justice ideals (Abdi, 2011; Asgharzadeh, 2008; Banks, 2006, 2009; Stromquist, 2007. Indeed, Marginson (2011) has reminded us that "the global dimension of higher education is not a sphere of nature" (p. 10); rather, it rests on the decisions and actions of people working within their institutions. While clearly influenced by and intersecting with globalization, internationalization remains the result of the choices and activities undertaken within our institutions. According to Altbach and Knight (2007), "globalization may be unalterable, but internationalization includes many choices" (p. 291). We should pay close attention our choices, since when internationalization aligns with globalization as inevitable and driven by the free market, it is easy to see how accountability for larger social issues can be overlooked.

\section{Internationalization and Globalization}

While internationalization undoubtedly creates benefits, particularly at the local level for Canadian institutions, the International Association of Universities (IAU) (2012) has identified a number of concerns regarding equity and access. The trading of education on the global market has fuelled internationalization in the last two decades, facilitated in part by the General Agreement on Trades and Services (GATS) (Knight, 2007). The 1995 inclusion of education as a tradable commodity in the GATS has exacerbated the situation in that many observable internationalization efforts, in particular the recruitment of international students and the cross-border sale of programs, have been viewed by some (Harris, 2008; Stromquist, 2007) as predominantly revenue-generation strategies. Although institutions pursued commercial cross-border arrangements prior to the inclusion of education in the GATS, many scholars see the GATS as the inevitable move to the full, global marketization of education, with its numerous potentially difficult or dangerous implications (Abdi, 2011; Altbach, 2004; Altbach \& Knight, 2007; Knight, 2007; Giroux, 2002; Harris, 2008 Stromquist, 2007), including increased inequity and limited access to education for those unable to pay.

The North/West domination of internationalized higher education also raises more than one concern. In some parts of the world, academics have limited access to resources or publication, which results in the big North/West universities dominating research and funding (Altbach, 2004; Webber, 2011), and the perpetuation of inequities in terms of access and opportunity. The larger issues are not only the economic repercussions but also the continued flavour of imperialism that follows from the provision of "superior" education by the North to the South or the West to the East (Andreotti, 2011). Abdi (2011) is 
perhaps the most outspoken scholar on this account. Outlining the complications of imperialist history, Abdi warns educators to be vigilant and not to complacently play into the colonialist attitudes of the past by overlooking the systemic and generational damages created by Eurocentric assumptions with respect to the peoples of the global South. He has reminded us that imperialist mindsets, including the post-colonial territorial assignments or support of "democratically" elected officials to rule newly created countries, have not only de-culturized and de-historized whole populations but also have been instrumental in de-citizenizing as well. Abdi has argued that the ideological preferences and assumptions of European (North/West) superiority coupled with historical amnesia are the most dangerous. Thus, Canadian institutions rushing to internationalize without consideration for equitable, inclusive, intercultural approaches should heed these warnings, or our current trajectory may be remembered as academic imperialism that failed to account for the assimilation of the multiple knowledges that were not deemed valuable in the current market.

Although almost 20 years ago the well-known internationalization scholar Joseph Mestenhauser (1998) advocated for an "educational reform that requires that we think differently about the universality of knowledge" (p. 21), the question of epistemological superiority has not been prevalent in most of the recent internationalization discourse. The main focus around cognitive inequity seems to be on the flows of intellect, either in the form of educational product or physically in the form of brain drain (IAU, 2012). Typically, the major flows of students are from South to North or East to West, whereas the flows of educational products are typically North to South or West to East. Altbach and Knight (2007) have conceded that in both cases, the South/East have received potential benefits, but the North/West still control the content and the economic benefits. Only Altbach (2004) has countered the assertion that the internationalization of higher education will inevitably level the playing field, when he noted the potential for a "loss of intellectual and cultural autonomy for those who are less powerful" (p. 9). Where we do find the attention of internationalization scholarship directed towards knowledge variations, or at least perspectives varied by cultural orientation, is in the work of the interculturalists or those who value intercultural frameworks beyond their usefulness for preparing students to negotiate the global economy (Asgharzadeh, 2008; Deardorff, 2006; Knight, 2004; Shultz, 2011; Otten, 2003, 2009) or facilitating their assimilation into North American educational contexts.

If internationalization is to avoid aligning education with potentially unethical or inequitable ideologies and practices, we should conscientiously interrogate the outcomes of decisions made to internationalize. Since the majority of Canadian institutions support the idea that internationalization is a vehicle towards graduating internationally and interculturally knowledgeable students (UNIVCAN, 2014), it will be necessary for us to critically review our approach, particularly when power and privilege are at play. We need to examine the rhetoric that internationalization can produce globally minded students on the one hand, while on the other potentially promoting a hegemonic monoculture and increased global inequity.

Although the reasons international students choose to study in Canada or other Westernized countries are many and varied-including gaining proficiency in English, fasttracked access to immigration, lack of access to higher education in their home countries, increased employability, and enhanced social capital-it is probable that many interna- 
tional students choose to come to the West/North due to varying understandings of what could be perceived as the superiority of the system or the potential to gain traction in the global marketplace. However, some also come for educational reasons tied to the needs of their home communities. How the dominant neoliberal ideology is filtered through the experiences of culturally diverse students who will become members of our society or who will carry this questionable orientation to their home countries around the globe also is a serious question. This positioning of one type of knowledge as superior (North/West) also may limit opportunities for an exchange of the rich cultural, epistemic, and social diversities within our student populations.

For internationalization to meet institutional goals and move beyond outputs to outcomes, it must address all students and campus personnel, rather than focus on mobility and the need for international students to be "integrated." Internationalization has the potential to benefit Canadian student learning, yet the majority of initiatives for Canadian students have focused on the $3 \%$ of Canadian students who study abroad (CBIE, 2015). For internationalization to reach its potential, we should be thinking about the other $97 \%$. One approach that advocates for all students to be exposed to intercultural and global learning is Internationalization at Home ( $\mathrm{I} @ \mathrm{H})$, which does not see mobility as a necessary requirement to achieve internationalized learning outcomes but rather focuses on the learning that can occur at the home campus through intentional curricular and pedagogical innovation.

\section{Internationalization at Home (I@H)}

Internationalization at home was first introduced in the 1990s in Sweden to address the competencies of the more than $90 \%$ of students who did not study abroad (Nilsson, 2003). Beelen and Jones (2015) have provided a new definition: $\mathrm{I} @ \mathrm{H}$ "is the purposeful integration of international and intercultural dimensions into the formal and informal curriculum for all students, within domestic learning environments" (p. 12). According to de Witt (2011), I@H arose as a "countermovement" to the European focus on mobility, in an attempt to address the more complex issues of curricula, co-curricula, and organizational culture changes necessary to broaden international learning outcomes for students. However, although the conceptualization of I@H may have developed as a challenge to the mobility focus, it is further challenged by the position of internationalization within a market framework.

As a local initiative intended to address teaching and learning on home campuses, $\mathrm{I} @ \mathrm{H}$ also has been fraught with obstacles introduced by other trends in education. For example, the attendant corporatization of the present model of education, which emphasizes competition and fiscal restraint, as in all public spheres, has put pressure on administrators to be accountable to the bottom line (Dale \& Robertson, 2009; Giroux, 2002; Nussbaum, 2009; Stromquist, 2007) rather than to global learning outcomes or issues of inclusivity that are the foundation of I@H. So, while institutions surveyed by Universities Canada (2014) have claimed that internationalization benefits student learning, financial realities have created the need for a level of international student tuition that is not normally dedicated to the creation of programing that supports I@H. However, the issue is more complex than local economics, since neoliberal ideology is reproduced and reinforced through educational forces (Asgharzadeh, 2008; Giroux \& Giroux, 2009; Kuok- 
kanen, 2007), and students are increasingly framed, and frame themselves, as consumers (Apple, 2000; Asgharzadeh, 2008; Côté \& Allahar, 2011; Kezar, 2004; Harris, 2007; Stromquist, 2007), as the following quote illustrates:

In the realm of commercialized education, students increasingly come to view education in the context of upward occupational and social mobility rather than as a means of developing the mind, enriching the intellect, and training conscientious, responsible, and socio-politically committed citizens. (Asgharzadeh, 2008, p. 335)

Numerous scholars have noted with alarm the prevalent shift toward pragmatic disciplines that support corporate employability, accompanied by a move away from the humanities (Altbach, 2004; Côté \& Allahar, 2011; Giroux, 2002; Kezar, 2007; Stromquist, 2007; Tilak, 2008), where the intercultural and global learning focus of I@H along with the attendant skills might be emphasized rather than merely being framed as résumé boosters (Andreotti, 2011). In the present atmosphere, the goal of education is to produce and reduce students to knowledge workers whose primary responsibility is to become "technically trained people who can hold onto 'our' share of the global market" (Nussbaum, 2009, p. 6). Indeed, Teichler (2004), perhaps naively, has commented that it is surprising that the current dialogue "focuses on marketisation, competition, and management in higher education; other terms such as knowledge society, global village, global understanding or global learning, are hardly taken into consideration” (p. 23). So, while $\mathrm{I} @ \mathrm{H}$ provides an avenue for internationalization to reach its more laudable goals, it may require a new story for all involved-from government and administrators to faculty and students-to shift paradigms.

To reach its full potential, the I@H approach will need to be broadly inclusive and introspective. Increasingly, scholarly voices are advocating for the inclusion of alternate epistemologies within our institutions (Andreotti, 2011; Asgharzadeh, 2008; Banks, 2009; Bates, 2005; Kincheloe \& Steinberg, 2008; Santos, 2006; Schoorman \& Bogotch, 2010). Thus, it may be timely for I@H to consider other frameworks that could help to align internationalization with more equitable and just outcomes. Critical global citizenship education may provide frameworks that support inclusion, social justice, and equity over market concerns.

\section{Global Citizenship Education}

Whereas the internationalization literature barely acknowledges whose knowledge is at risk or whose knowledge is being widely distributed, the global citizenship education (GCE) literature is filled with warnings to consider other epistemological orientations in the quest for global-mindedness. GCE is positioned to interrogate both concepts-global and citizenship-particularly by scholars cognizant of the historical impositions of culture and norms, who have argued that any substantial global education curriculum necessarily requires more than a dominant perspective (Abdi, 2011; Andreotti, 2011; Pike, 2008; Swanson, 2011). Implicit in GCE's calls for "epistemological pluralism" (Andreotti, 2011) is the inclusion of Indigenous world views and perspectives, without which hegemony will continue to prevail (Swanson, 2011). Many feel that not to consider alternate knowledge frameworks would be tantamount to a perpetuation of colonial subjugation. Abdi (2011) has framed his position within a historical context: 
The relationship between the West and the rest of the world has not been a mutual understanding of the certain commonalities of the global public good. It was, undoubtedly, the mono-directional ideological stampede that believes in itself and cannot ascertain other intentions and possibilities of life. (p. 27)

These considerations lead us back to how and what we teach and whether students are leaving our institutions with merely information or also with frameworks to understand others and the world.

Similar to the internationalization literature, scholars of GCE also have faced the challenge of providing a widely recognized definition of the field (Abdi \& Shultz, 2008, Abdi, 2011; Davies, 2006; Dower, 2008; Pike, 2008; Shultz, 2011; Swanson, 2011). While Pike (2000) identified the key elements of GCE as developing awareness of interdependence, connectedness, and perspective, eight years later he admitted that the concept of a global citizen often has been appropriated by neoliberal sentiments to convey global market competence or even employment that involves numerous international flights (Pike, 2008). The sentiment that the concept of global citizenship may be used increasingly to promote market interests also has been noted by Guimaraes-Iosif (2011), Shultz, Abdi, and Richardson (2011), Swanson (2011), and Weber (2011). Swanson (2011) has noted that the increase in institutional support for global citizenship initiatives rides on the competitive increase in all things international and often serves merely to legitimate mission statements and branding that promote "cutting-edge" education.

Most recent GCE scholarship has acknowledged the tensions and potential difficulties posed by the lack of a coherent definition, yet, at the same time, seems willing to accept the ambiguity so as to continue the dialogue, which it considers more important than a choice of vocabulary or definitional clarity (Davies, 2006; Pike, 2008; Tarc, 2011). Shultz (2008, 2011), as the co-editor of two volumes dedicated to global citizenship education, readily admitted that the "rich diversity of locations and discourses might suggest that the term 'global citizenship' has become emptied of its meaning" (Shultz, 2011, p. 14), and yet, she contended that it is exactly in this rich and contested scholarship that the concept may hold its greatest potential. Perhaps it is this potential that can be harnessed to inform a reframing of internationalization; the definitional uncertainty of global citizenship education could provide a platform for the much-needed discourse surrounding internationalization claims.

\section{Global Citizenship and Internationalization}

Recently, higher education has had a revival of interest in global citizenship, seemingly influenced by opportunities surrounding internationalization (Asgharzadeh, 2008; Gacel-Avila, 2005; Shultz, 2011; Swanson, 2011; Tarc, 2011). However, a review of the GCE literature reveals a number of shifts from the internationalization literature, including: (i) a heightened emphasis on the ethical dilemmas presented by globalization and internationalization (Abdi, 2011; Asgharzadeh, 2008; Swanson, 2011); (ii) a wider disciplinary distribution of interest in global citizenship in relation to fields beyond social studies (Krogman \& Foote, 2011; Shultz, 2011; Webber, 2011); and (iii)) a focus on pedagogy and curriculum development (Andreotti, 2011; Shultz, 2011; Swanson, 2011; Tarc, 2011). Moreover, GCE scholarship has revealed the tensions around who qualifies 
as global citizens (Dower, 2008; Swanson, 2011; Tarc, 2011) and how citizenship can even be conceptualized on a global scale (Abdi, 2011; Shultz, 2011).

These discourses are important for moving internationalization to an outcomes approach. How students understand intercultural and global learning will be influenced undoubtedly by the perspective of educators on the inevitability of neoliberal globalization or the possibility of alternative frameworks acknowledging human agency in navigating the impacts of rapid change and interdependence. Educators must take care to encourage critical thinking by presenting multiple perspectives for consideration, so students can grapple with the complex issues of our times. Internationalization efforts have fallen short of a substantial focus on learning outcomes. Certainly, although widespread sentiments exist that internationalization benefits students, and some courses have these specific outcomes, they are not necessarily tied to internationalization per se, and to my knowledge, currently no Canadian institution can claim these outcomes for the majority of its students across disciplines. Rather, most of these outcomes seem to be institutional rhetoric that is neither required of all students nor formally assessed. Contrary to the rhetoric of internationalization, substantive intercultural learning does not simply happen as a result of increased diversity (Arkoudis et al., 2012; Bennett, 2012; Knight, 2011; Leask, 2010; Lee, Poch, Shaw, \& Williams, 2012). As noted earlier, increasing empirical evidence exists that structural diversity-when diversity is represented on campus-is an "insufficient condition for maximal educational benefits" (Gurin, Dey, Hurtado, \& Gurin, 2002, p. 333). To the contrary, the intergroup contact theory that has informed a half a century of research has indicated that attention to proper conditions and preparing people to work across difference is necessary for positive interaction and learning to occur (Allport, 1954; Pettigrew \& Tropp, 2006; Sidanius, Levin, van Larr, \& Sears, 2008). All of this signals the need to intentionally and critically engage with the "why" of internationalization and to reframe the approach to focus on student learning.

\section{A Way Forward}

Although Brandenburg and de Witt (2011) have maintained that it is time to rethink internationalization as a means to a goal, one forward-looking educational goal might be connecting internationalization more explicitly to intercultural and global learning outcomes that promote critical global citizenship orientations. Considering that we are educating students during a time of unprecedented mobility and interaction of populations and ideas, it would seem prudent to provide opportunities for them to develop the knowledge and skills necessary to navigate intercultural and global issues within both their disciplines and their communities. In the Canadian context, this development becomes increasingly important as we continue to become a more multicultural society while, at the same time, we attempt to reconcile our history with First Nations peoples. When framed within the context of intercultural and global learning for all students-with a particular emphasis on the inclusion, equity, multiple perspectives, and pedagogies advocated by critical GCE-internationalization could play a part in creating a better society. According to Asgharzadeh (2008):

We need a vision of international education that pays attention to the educational and social needs of multicultural student populations. To this end, policies and 
practices of teaching, learning, and educational delivery need to move away from conventional methods based on monolingualism and monoculturalism. Such a shift should be reflected in teacher training courses, development of curricula, and design of the school environment where emphasis is placed on cross-cultural, sociopolitical, and sociohistorical aspects of interrelations between and among sites such as language, identity, and power. (p. 340)

The internationalization literature has, for the most part, downplayed the socio-political and socio-historical implications of language, power, and identity that Asgharzadeh (2008) has recommended addressing. Aligning I@H goals with GCE may open a way forward. GCE scholarship could inform a number of areas for a new understanding of internationalization. First, whereas internationalization has not traditionally been concerned with how a dominant epistemology has been championed, GCE scholars have advocated for the inclusion of multiple perspectives and epistemologies (Andreotti, 2011; Appiah, 2006; Asgharzadeh, 2008; Banks, 2009; Bates, 2005; Kincheloe \& Steinberg, 2008; Santos, 2007; Schoorman \& Bogotch, 2010). Second, GCE scholarship's attempt to explicitly address the inequities and ethical dilemmas surrounding globalization could benefit internationalization in making a move towards an outcomes focus. Finally, GCE has maintained a focus on pedagogy and curriculum that centers on student learning.

Furthermore, to create a campus ethos that nurtures global mindedness, all campus personnel need clear communication regarding the rationales for internationalization and intercultural and global learning as part of the campus culture (Anderson, 2008). This concept of a campus ethos that would reach all areas of the institution is in line with Hudzik's (2011) definition of comprehensive internationalization discussed earlier, which endorses a view of internationalization that is part of the university mission in learning and teaching, research, and service. The concept of ethos is further supported by de Witt et al.'s (2015) definition that highlights the positive contribution of internationalization to society. If Canadian higher education is to play a role in preparing young people to be effective citizens in an increasingly interconnected world, it will require connecting internationalization to student learning, with the academic and social rationales both supported. This role will necessitate institutional change that values linking intercultural and global learning outcomes to academic excellence, pedagogy, and curricular transformation (Anderson, 2008).

The internationalization of higher education will remain a priority for the foreseeable future due to the various local and global influences discussed in earlier sections of this paper. However, the path of internationalization in Canada remains to be seen. The direction and outcomes of internationalization efforts in the Canadian context should be debated and decisions carefully considered for the potential to promote inclusion, equity, and social justice rather than merely revenue generation. Blades and Richardson (2006) have contended that educators are faced with a moral imperative to address the inequities and social injustices that continue to be the result of our hegemonic and uncritical frameworks. If internationalization discourse continues to be dominated by neoliberal economic frameworks, it runs the risks of not only missing its articulated goals but being remembered as a vehicle that inadvertently supported domination or inequity as a result of the distraction of market pressures. Therefore, Canadian educators should critically examine the rationales for, and outcomes of, the internationalization of our campuses. 


\section{References}

Abdi, A.A., \& Shultz, L. (2008). Educating for human rights and global citizenship: An introduction. In A.A. Abdi \& L. Shultz (Eds.). Educating for human rights and global citizenship (pp.1-11). Albany, NY: State University of New York Press.

Abdi, A. A. (2011). De-monoculturalizing global citizenship education: The need for multicentric intentions and practices. In L. Shultz, A. A. Abdi, \& G. H. Richardson (Eds.), Global citizenship education in post-secondary institutions: Theories, practices, policies (pp. 25-39). New York, NY: Peter Lang Publishing.

Allport, G. W. (1954). The nature of prejudice. Garden City, NY: Doubleday \& Co.

Altbach, P. G. (2004). Globalization and the university: Myths and realities in an uneven world. Tertiary Education and Management, 1O(1), 3-25.

Altbach, P. G., \& Knight, J. (2007). The internationalization of higher education: Myths and realities. Journal of Studies in International Education, 11(3-4), 290-305.

Altbach, P. G., \& Teichler, U. (2001). Internationalization and exchanges in a globalized university. Journal of Studies in International Education, 5(1), 5-25. doi:10.1177/102831530151002

Anderson, J. A. (2008). Driving change through diversity and globalization: Transformative leadership in the academy. Sterling, VA: Stylus.

Andreotti, V. (2011). The question of the "other" in global citizenship education: Postcolonial analysis of telling case studies in England. In L. Shultz, A. A. Abdi, \& G. H. Richardson (Eds.), Global citizenship education in post-secondary institutions: Theories, practices, policies (pp. 140-157). New York, NY: Peter Lang Publishing.

Appadurai, A. (Ed.). (2001). Globalization. Durham, NC: Duke University Press.

Appiah, K. A. (2006). Cosmopolitanism: Ethics in a world of strangers. New York, NY: Norton \& Co.

Apple, M. W. (2000). Between neoliberalism and neoconservatism: Education and conservatism in a global context. In N. C. Burbules \& C. A. Torres (Eds.), Globalization and education: Critical perspectives (pp. 57-77). New York, NY: Routledge.

Arkoudis, S., Yu, X., Baik, C., Borland, H., Chang, S., Lang, L., . . Watty, K. (2010). Finding common ground: Enhancing interaction between domestic and international students. Sydney, Australia: Australian Learning and Teaching Council. Retrieved from http://melbourne-cshe.unimelb.edu.au/research/experience/finding-common-ground

Asgharzadeh, A. (2008). The return of the subaltern: International education and politics of voice. Journal of Studies in International Education, 12(4), 334-363. doi:10.1177/1028315307308137

Banks, J. A. (2006). Democracy, diversity, and social justice: Educating citizens for the public interest in a global age. In G. Landson-Billings, \& W. F. Tate (Eds.), Education research in the public interest: Social justice, action, and policy (pp. 141-157). New York, NY: Teachers College Press. 
Banks, J. A. (2009). Human rights, diversity, and citizenship education. Educational Forum, 73(2), 100-110. doi:10.1080/00131720902739478

Bates, R. (2005). Can we live together?: Towards a global curriculum. Arts and Humanities in Higher Education: An International Journal of Theory, Research and Practice, 4(1), 95-109. doi:10.1177/1474022205048760

Beck, K. (2008). Being international: Learning in a Canadianuniversity (Unpublished doctoral dissertation). Simon Fraser University, Burnaby, BC.

Beck, K.(2012).Globalization/s: Reproductionandresistanceintheinternationalization of higher education. Canadian Journal of Education/Revue Canadienne de L'éducation, 35(3), 133-148.

Beelen, J., \& Jones, E. (2015). Europe calling: A new definition for internationalization at home. International Higher Education, 83, special issue, 12-13.

Bennett, M. (2012, February 15). Turning cross-cultural contact into intercultural learning. Paper presented at the Universidad 2012 8th International Congress on Higher Education, The University for Sustainable Development, Havana, Cuba.

Blades, D. W., \& Richardson, G. H. (2006). Restarting the interrupted discourse of the public good: Global citizenship education as moral imperative. In G. H. Richardson \& D. W. Blades (Eds.), Troubling the canon of citizenship education (pp. 115-123). New York, NY: Peter Lang Publishing.

Bond, S. (2006). Transforming the culture of learning: Evoking the international dimension in Canadian university curriculum. Paper presented at the York University/ Ontario Confederation of University Faculty Associations Symposium: "Internationalizing Canadian Universities: Practices, Challenges and Opportunities." Retrieved from http://www.queensu.ca/teachingandlearning/modules/globalization/documents/ Transforming\%20the\%20Culture\%20of\%20Learning_Sheryl-Bond.pdf

Bourdieu, P. (2003). Firing back: Against the tyranny of the market 2 (L. Wacquant, Trans.). New York, NY: Raisons d'Agir Editions.

Brandenburg, U., \& de Wit, H. (2011). The end of internationalization. International Higher Education, 62(Winter), 15-16.

Burbules, N. C., \& Torres, C. A. (2000). Globalization and education: An introduction. In N. C. Burbules \& C. A. Torres (Eds.), Globalization and education: Critical perspectives (pp. 1-26). New York, NY: Routledge.

Camicia, S. P., \& Franklin, B. M. (2010). Curriculum reform in a globalised world: The discourses of cosmopolitanism and community. London Review of Education, 8(2), 93-104.

Canada (2014). Canada's international education strategy: Harnessing our knowledge advantage to drive innovation and prosperity. Retrieved from http://international. gc.ca/global-markets-marches-mondiaux/education/strategy-strategie.aspx?lang=eng. Ottawa, ON: Author 
Canadian Bureau for International Education (CBIE). (2013). A world of learning: Canada's performance and potential in international education. Ottawa, ON: Author.

Canadian Bureau for International Education (CBIE). (2015). A world of learning: Canada's performance and potential in international education. Ottawa, ON: Author.

Conversi, D. (2010). The limits of cultural globalization. Journal of Critical Globalization Studies, (3), 36-59.

Côté, J., \& Allahar, A. (2011). Lowering higher education: The rise of corporate universities and the fall of liberal education. Toronto, ON: University of Toronto Press.

Dale, R., \& Robertson, S. (2009). Capitalism, modernity and the future of education in the new social contract. In T. Popkewitz \& F. Rizvi (Eds.), Globalization and the study of education (pp. 111-129). Chicago, IL: Wiley Blackwell, National Society for the Study of Education, \& 108th NSSE Yearbook.

Davies, L. (2006). Global citizenship: Abstraction or framework for action? Educational Review, 58(1), 5-25.

de Witt, H. (2009). Measuring success in the internationalisation of higher education: An introduction. In H. de Witt (Ed.), Measuring success in the internationalisation of higher education (EAIE Occasional Paper 22; pp. 1-8). Amsterdam, The Netherlands: European Association for International Education. Retrieved from: http://aplicaciones2. colombiaaprende.edu.co/mesas_dialogo/documentos/mesa80/2057Measuringinternas ionalisationEAIE.pdf

de Wit, H. (2011). Internationalisation of the universities of applied sciences: Misconceptions and challenges. In Trends, Issues and Challenges in Internationalisation of Higher Education (pp. 7-24). Amsterdam, The Netherlands: Centre for Applied Research on Economics \& Management, School of Economics and Management, Hogeschool van Amsterdam.

de Witt, H., Hunter, F., Howard, L., \& Egron-Polak, E. (2015). Internationalisation of higher education. Brussels, Belgium: Policy Department B: Structural Cohesion Policies, European Parliament. Retrieved from http://www.europarl.europa.eu/RegData/etudes/ STUD/2015/540370/IPOL_STU(2015)540370_EN.pdf

Deardorff, D. K. (2006). Identification and assessment of intercultural competence as a student outcome of internationalization. Journal of Studies in International Education, 1O(3), 241-265. doi:10.1177/1028315306287002

Dower, N. (2008). Are we all global citizens or are only some of us global citizens?: The relevance of this question to education. In A. A. Abdi \& L. Shultz (Eds.), Educating for human rights and global citizenship (pp. 39-54). Albany, NY: State University of New York Press.

Enders, J. (2004). Higher education, internationalisation, and the nation-state: Recent developments and challenges to governance theory. Higher Education: The International Journal of Higher Education and Educational Planning, 47(3), 361-382.

Friedman, T. L. (2005). The world is flat: A brief history of the twenty-first century. New York, NY: Farrar, Straus and Giroux. 
Gacel-Avila, J. (2005). The internationalisation of higher education: A paradigm for global citizenry. Journal of Studies in International Education, 9(2), 121-136. doi:10.1177/1028315304263795

Garson, K. (2013). Are we graduating global citizens? A mixed methods study investigating students' intercultural development and perceptions of intercultural and global learning in academic settings (Unpublished doctoral dissertation). Simon Fraser University, Burnaby, BC.

Gaudelli, W. (2009). Heuristics of global citizenship discourses towards curriculum enhancement. Journal of Curriculum Theorizing, 25(1), 68-85.

Giroux, H. A. (2002). Neoliberalism, corporate culture, and the promise of higher education: The university as a democratic public sphere. Harvard Educational Review, 72(4), 425-63.

Giroux, H. A., \& Giroux, S. S. (2009). Beyond bailouts: On the politics of education after neoliberalism. Policy Futures in Education, 7(1), 1-4.

Grayson, J. P. (2008). The experiences and outcomes of domestic and international students at four Canadian universities. Higher Education Research and Development, 27(3), 215-230. doi:10.1080/07294360802183788

Guimaraes-Iosif, R. (2011). Rethinking citizenship education in higher education institutions through the lens of critical pedagogy: Educating the local and global emancipated citizen. In A. A. Abdi \& G. H. Richardson (Eds.), Global citizenship education in post-secondary institutions: Theories, practices, policies (pp. 76-93). New York, NY: Peter Lang Publishing.

Gurin, P., Dey, E., Hurtado, S., \& Gurin, G. (2002). Diversity and higher education: Theory and impact on educational outcomes. Harvard Educational Review, 72(3), 330366.

Harris, S. (2008). Internationalizing the university. Educational Philosophy and Theory, 4O(2), 346-357. doi:10.1111/j.1469-5812.2007.00336.x

Hudzik, J. K. (2011). Comprehensive internationalization: From concept to action. Washington,

DC: NAFSA, The Association of International Educators.

International Association of Universities. (2012). Affirming academic values in internationalization of higher education: $A$ call to action. International Universities Bureau. Retrieved from http://www.iau-aiu.net/sites/all/files/Affirming_Academic_ Values_in_Internationalization_of_Higher_Education.pdf

Jones, A. (2010). Globalization: Key thinkers. Malden, MA: Polity Press.

Kezar, A. (2004). Obtaining integrity? Reviewing and examining the charter between higher education and society. The Review of Higher Education, 27(4), 429-559.

Kincheloe, J., \& Steinberg, S. (2008). Indigenous knowledges in education: Complexities, dangers, and profound benefits. In N. K. Denzin, Y.S. Lincoln, \& L. Tuhiwai Smith (Eds.), Handbook of critical and Indigenous methodologies (pp. 135-156). Thousand Oaks, CA: Sage. 
Klein, N. (2000). No logo. Toronto, ON: Random House.

Klein, N. (2008). The shock doctrine: The rise of disaster capitalism. Toronto, ON: Random House.

Knight, J. (2004). Internationalization remodeled: Definition, approaches, and rationales. Journal of Studies in International Education, 8(1), 5-31. doi:10.1177/1028315303260832

Knight, J. (2007) Cross-border tertiary education: An introduction. Cross-border tertiary education: A way towards capacity development (pp. 21-46). Paris, France: OECD, World Bank, \& NUFFIC.

Knight, J. (2011). Five myths about internationalization. International Higher Education, 62, 14-15.

Krogman, N., \& Foote, L. (2011). Global citizenship and the environment: Embracing life in all its forms. In L. Shultz, A. A. Abdi, \& G. H. Richardson (Eds.), Global citizenship education in post-secondary institutions: Theories, practices, policies (pp. 108-119). New York, NY: Peter Lang Publishing.

Kuokkanen, R. (2007). Reshaping the university: Responsibility, indigenous epistemes, and the logic of the gift. Vancouver, BC: UBC Press.

Kuokkanen, R. (2008). What is hospitality in the academy? Epistemic ignorance and the (im)possible gift. The Review of Education, Pedagogy, and Cultural Studies, 3o(1), 6o-82. doi:10.1080/10714410701821297

Leask, B. (2010). "Beside me is an empty chair": The student experience of internationalisation. In E. Jones (Ed.), Internationalization and the student voice: Higher education perspectives (pp. 3-17). New York, NY: Routledge.

Leask, B. (2012). Internationalization of the curriculum (IoC) in action: A guide. Sydney, Australia: University of South Australia.

Lee, A., Poch, R., Shaw, M., \& Williams, R. D. (2012). Engaging diversity in undergraduate classrooms: A pedagogy for developing intercultural competence. ASHE Higher Education Report, Volume 38(2). San Francisco, CA: Wiley Periodicals.

Marginson, S. (2011). Higher education and the public good. Higher Education Quarterly, 64(4), 411-433.

Mestenhauser, J. A. (1998). Portraits of an international curriculum: An uncommon multidimensional perspective. In J. A. Mestenhauser \& B. J. Ellingboe (Eds.), Reforming the higher education curriculum: Internationalizing the campus (pp. 3-39). Phoenix, AZ: Oryx Press.

Nilsson, B. (2003). Internationalisation at home from a Swedish perspective: The case of Malmö. Journal of Studies in International Education, 7(27), 27-40. doi:10.1177/1028315302250178

Nussbaum, M. C. (2009). Education for profit, education for freedom. Liberal Education, 95(3), 6-13. 
Oka, K.U.(2007).Pedagogy of the global: Knowledge, empireandinternationalization in the university (Unpublished doctoral dissertation). University of Toronto, Toronto, $\mathrm{ON}$.

Otten, M. (2003). Intercultural learning and diversity in higher education. Journal of Studies in International Education, 7(1), 12-36. doi:10.1177/1028315302250177

Otten, M. (2009). Academicus interculturalis? Negotiating interculturality in academic communities of practice. Intercultural Education, 20(5), 407-417. doi:10.1080/14675980903371266

Paige, R. M., \& Mestenhauser, J. A. (1999). Internationalizing educational administration. Educational Administration Quarterly, 35(4), 500-517.

Pettigrew, T. F., \& Tropp, L. R. (2006). A meta-analytic test of intergroup contact theory. Journal of Personality and Social Psychology, 9o(5), 751-783. doi:10.1037/00223514.90 .5 .751

Pike, G. (2000). A tapestry in the making: The strands of global education. In T. Goldstein \& Selby (Eds.), Weaving connections: Educating for peace, social and environmental justice (pp. 218-241). Toronto, ON: Sumach Press.

Pike, G. (2008). Reconstructing the legend: Educating for global citizenship. In A. A. Abdi \& L. Shultz (Eds.), Educating for human rights and global citizenship (pp. 223238). Albany, NY: State University of New York Press.

Popkewitz, T., \& Rizvi, F. (Eds.).(2009). Globalization and the study of education. Chicago, IL: Wiley Blackwell, National Society for the Study of Education, \& 108th NSSE Yearbook.

Santos, B. d. S. (2006). Globalizations. Theory, Culture \& Society, 23(2-3), 393-396.

Santos, B. d. S. (2007). Another knowledge is possible: Beyond northern epistemologies. London, UK: Verso.

Santos, B. d. S. (2012). The university at a crossroads. Human Architecture: Journal of the Sociology of Self-Knowledge, 10(1), 7-16.

Schoorman, D., \& Bogotch, I. (2010). Moving beyond "diversity" to "social justice": The challenge to re-conceptualize multicultural education. Intercultural Education, 21(1), 79-85. doi:10.1080/14675980903491916

Shultz, L. (2011). Engaging the multiple discourses of global citizenship education within a Canadian university: Deliberation, contestation, and social justice possibilities. In L. Shultz, A. A. Abdi, \& G. H. Richardson (Eds.), Global citizenship education in postsecondary institutions: Theories, practices, policies (pp. 13-24). New York, NY: Peter Lang Publishing.

Shultz, L., Abdi, A. A., \& Richardson, G. H. (2011). Global citizenship education and the role of the academy: A critical introduction. In L. Shultz, A. A. Abdi, \& G. H. Richardson (Eds.), Global citizenship education in post-secondary institutions: Theories, practices, policies (pp. 1-12). New York, NY: Peter Lang Publishing.

Sidanius, J., Levin, S., van Larr, C., \& Sears, D. O. (2008). The diversity challenge: Social identity and intergroup relations on the college campus. New York, NY: Russell Sage Foundation. 
Statistics Canada. (2011). Projections of the diversity of the Canadian population. Retrieved from http://www.statcan.gc.ca/daily-quotidien/100309/dq100309a-eng.htm

Stromquist, N. P. (2007). Internationalization as a response to globalization: Radical shifts in university environments. Higher Education: The International Journal of Higher Education and Educational Planning, 53(1), 81-105. doi:10.1007/s10734-0051975-5

Stromquist, N. P., \& Monkman, K. (2014). Globalization and education: Integration and contestation across cultures (2nd ed.). Lanham, MD: Rowman and Littlefield.

Swanson, D. (2011). Parallaxes and paradoxes of global citizenship: Critical reflection and possibilities of praxis in/through an international online course. In L. Shultz, A. A. Abdi, \& G. H. Richardson (Eds.), Global citizenship education in post-secondary institutions: Theories, practices, policies (pp. 120-139). New York, NY: Peter Lang Publishing.

Tarc, P. (2011). Bridging (representations of) the "global present" with the life-world of the classroom: Researching toward "learning to teach" global citizenship education. In L. Shultz, A. A. Abdi, \& G. H. Richardson (Eds.), Global citizenship education in postsecondary institutions: Theories, practices, policies (pp. 64-75). New York, NY: Peter Lang Publishing.

Tiechler, U. (2004). The changing debate on internationalization of higher education. Higher Education, 48(1), 5-26.

Tilak, J. B. G. (2008). Higher education: A public good or a commodity for trade? Commitment to higher education or commitment of higher education to trade. Prospects, 38(4), 449-446. doi:10.1007/s11125-009-9093-2

Universities Canada (UNIVCAN). (2014). Canada's universities in the world: AUCC Internationalization Survey. Ottawa, ON: Author. Retrieved from https://www.univcan. ca/wp-content/uploads/2015/o7/internationalization-survey-2014.pdf

Universities Canada. (2015). Closing Canada's Indigenous education gap. Retrieved from http://www.univcan.ca/wp-content/uploads/2015/o9/issue-closing-canadasindigenous-gap-oct-20151.pdf

Weber, N. (2011). Global education in higher education institutions in Ireland, the United Kingdom and Canada: Complementarity and conflict in the global university. In A. A. Abdi, L. Shultz, \& G. H. Richardson (Eds.), Global citizenship education in postsecondary institutions: Theories, practices, policies (pp. 249-259). New York, NY: Peter Lang Publishing.

Wright, R. (2004). A short history of progress. Toronto, ON: House of Anansi Press.

\section{Contact Information}

Kyra Garson

Centre for Student Engagement and Learning Innovation Thompson Rivers University

kgarson@tru.ca 
Kyra is a faculty member at Thompson Rivers University in the Centre for Student Engagement and Learning Innovation. Her research interests include intercultural and global learning, internationalization leadership, and faculty development. Kyra's doctoral study on these topics received the Canadian Society for the Study of Higher Education's dissertation of the year award in 2014. In 2011, she received the Canadian Bureau for International Education's Internationalization Award for her work supporting faculty in internationalization. 